\title{
Between life and death
}

\author{
Mummies: The Dream of Everlasting Life \\ South Tyrol Museum of Archaeology, \\ Bolzano, Italy \\ Until 25 October 2009 \\ www.iceman.it
}

The preserved Tyrolean Iceman Ötzi is joined by 70 mummies, many displayed for the first time, in an exhibition that opened this week at the South Tyrol Museum of Archaeology in Bolzano, Italy. Mummies: The Dream of Everlasting Life examines the science and culture of mummification, with diverse examples of humans and animals preserved in various ways and drawn from South America and Asia to ancient Egypt.

Curated together with the ReissEngelhorn-Museums in Mannheim, Germany, the collection includes 20 mummies that were discovered in that museum's basement during renovations in 2004. Thought to have been lost, they had been hidden there for protection during the Second World War.

Ötzi the Iceman, the exhibition's host, was found frozen into a glacier in the Ötzal Alps near the Austria-Italy border in 1991. He died there from an arrow wound to the shoulder around
$3300 \mathrm{BC}$, and is thought to have been a hunter, although his identity is unclear. "Since Ötzi cannot leave the museum," explains Bolzano archaeologist Andreas Putzer, "this is a unique occasion to see these mummies together."

The different stages of mummification in ancient Egypt are revealed in a series of partially preserved bodies. A mummified three-year-old Peruvian child from the fifteenth century represents the first evidence from South America

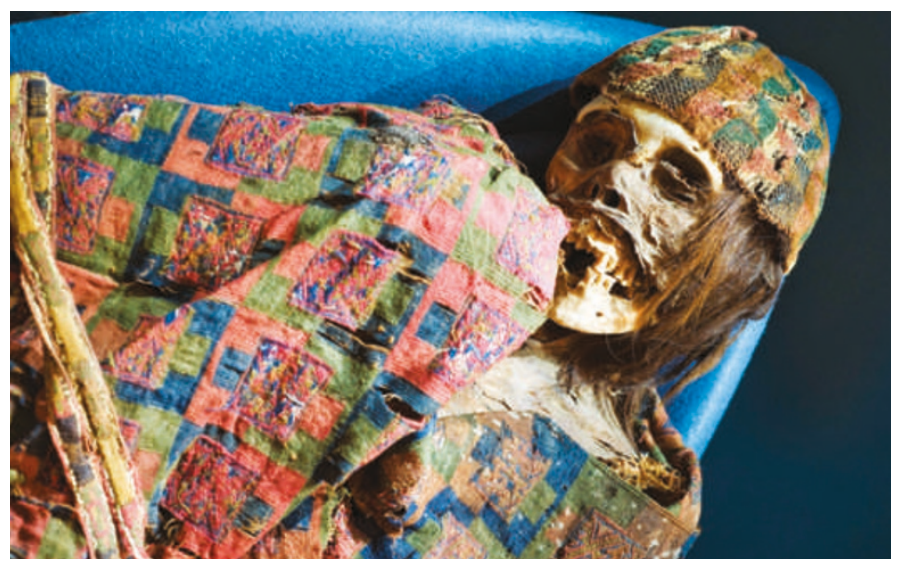

The rich clothes of this 500-year-old Inca mummy suggest a high social status.

baron from a cellar in Castle Sommersdorf near Nuremberg, Germany, are more recent European examples. Their bodies were dried using artificial air-conditioning systems. "We want to explode the myth that mummies are only from Egypt," says curator Wilfried Rosendahl from the Reiss-Engelhorn-Museums.

A range of mummified animals on display include the only known animal mummy found in a bog - a domesticated dog from the sixteenth century, found near Münster in Germany - and naturally preserved examples, including dinosaurs, from varied environments such as deserts, bogs and caves, or under ice or salt.

Related burial offerings and scientific information are shown beside the mummies. Anthropology, genetics, pathology, toxicology and medical studies provide clues about their living conditions, dietary habits and diseases.

Mummification continues to this day as an alternative to burial or cremation. Methods range from those used in ancient Egypt to cryogenic freezing of the brain, with the hope that one day it will be possible to grow a new body from brain cells by means of DNA replication. "Mummies still trigger a

of embalming a human corpse with resin, the same technique that was used in Egypt. An eighteenth-century mummified family found in a Hungarian church and a mummified deep interest because they represent something between life and death," says Rosendahl.

Marta Paterlini is a journalist based in Stockholm. e-mail:martapaterlini@nasw.org

\section{A gallery of chimaeric curiosities}

\section{Corpus Extremus (LIFE+) \\ Exit Art, 475 Tenth Avenue, New York Until 18 April 2009. \\ www.exitart.org}

When images of the Vacanti mouse, the mouse with a cartilage ear growing on its back, were released in 1997, it seemed that a surrealist project had come alive. Although the experiment was a step towards using living material for tissue engineering, the surprising and provocative juxtaposition of body parts was also a culturally evocative artefact - an art piece.

The exhibition Corpus Extremus (LIFE+), at New York's Exit Art until 18 April, examines the effect of biotechnology on our notions of life and death. Diverse works include living matter, and reflect on the creation of new organisms hybrids, cyborgs and extended human bodies.

A cabinet of chimaeric curiosities explores the taxonomical crisis that is presented by new life forms in NoArk II, by Oron Catts and Ionat Zurr of SymbioticA, the biological art centre at the University of Western Australia near Perth. They display masses of living cells taken from different organisms alongside preserved museum specimens. Skin and blood cells are used as a screen on which movies are projected in another installation by the BioKino collaboration, a reference to early science films.

The Mirror of Faith, an installation by the Ultrafuturo group, is an attempt to create "selftranscendent" bacteria that carry VMAT2, the gene controversially claimed by some to cause higher consciousness and spirituality in humans.

Other works embrace robotics. A culmination of six years of research by artists Guy Ben-Ary and Philip Gamblen, Silent Barrage evokes the human machine and futuristic communication interfaces. A robotic body made of 36 connected parts is controlled by electrical signals in a network of rat neurons growing in a remote Petri dish in Steve Potter's lab at the Georgia Institute

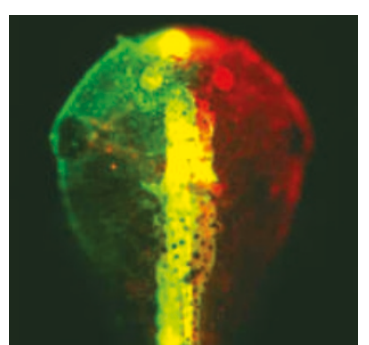

A fluorescing tadpole reveals its previously unseen developmental secrets. of Technology in Atlanta.

Ironic, critical and Utopian, the exhibition raises issues about artificially cultured cells, the presumed uniqueness of human life, our anthropocentric hierarchies and the possibility of engineered and commodified perfection.

Giovanni Frazzetto is a Society in Science Branco Weiss Fellow at the BIOS Centre, London School of Economics, Houghton Street, London WC2A 2AE,

UK, and is at the European Molecular Biology Laboratory, 00015 Monterotondo, Italy. e-mail:g.frazzetto@lse.ac.uk 